\title{
Congolese Child Soldier Narratives for Global and Local Audiences
}

\section{From Testimony to Reconciliation}

\author{
Susanne Gehrmann | ORCID: 0000-0003-4462-7836 \\ Humboldt-Universität zu Berlin, Berlin, Germany \\ susanne.gehrmann@rz.hu-berlin.de
}

\begin{abstract}
The article examines narratives by and about former child soldiers in the Democratic Republic of the Congo, a hitherto neglected corpus despite the topicality of child soldiering in African literatures after 2000. Critical readings of three testimonial texts that have been published in France are juxtaposed with the analysis of one testimonial narrative and one youth novel that have been published in Kinshasa. The editorial framing and narrative strategies that speak to different audiences located in different literary fields are identified. The popularity of testimonial narratives in the West relies on the depiction of violence and the iconic function of the child soldier in medial and human rights discourses. By contrast, narratives about the reconciliation and the reintegration of child soldiers prevail in the DRC. Thus, the different functions of global and local narratives on the sensitive issue of children at war are exposed.
\end{abstract}

\section{Keywords}

literature of the DRC - child soldiers - testimony - editorial framing - audiences

\section{Introduction}

In Fiston Mwanza Mujila's novel Tram 83 (2014), the narrator speaks about a typology of different social groups in a fictional city that mixes features of Lubumbashi and Kinshasa. Mujila enumerates the city's riff-raff, including "the single-mamas, the human organ dealers, the child soldiers with their Kalashnikovs, the apostles, the night waitresses and busgirls, the musicians from for- 
mer Zaire, the bandits, and other burglars" (23). While in Mujila's novel, child soldiers are not in the center of the narration, they are nevertheless a visible part of Tram 83's psychedelic urban landscape and its omnipresent lumpenproletariat, together with petty criminals and sex workers united in the art of resourcefulness to survive in a chaotic city. The Kalashnikov becomes a personified double of the child soldier or the kadogo, ${ }^{1}$ and a metonym of the everpresent violence in a postwar society.

Tram 83 is a good example of the subgenre of those contemporary African novels that the Cameroonian critic and novelist Patrice Nganang describes as the "garbage novel"2 (273). Nganang employs this term to speak about works of fiction that no longer focus on the mighty or the intellectuals of African societies, as was often the case in the 1970s and 1980s, but instead on the marginalized of society. The child soldier is a prominent literary character of this trend, and, as I have argued elsewhere (Gehrmann 33), the child soldier constitutes a trope that serves as an allegorical counter-figure to the formerly dominating African dictator. The topic of child soldiers was particularly prominent in African and Afrodiasporic literatures in English and French in the 20oos. It has produced at least two branches of narratives: autobiographical testimonies by ex-combatants, and fictional accounts - particularly in novels, but also in short stories and plays. "It touches us, therefore, we speak about it"3 (Waberi "Cela nous touche" 57), confirms Abdourahman Waberi in the plural voice of a presumed collective of African writers. ${ }^{4}$ The popularity boom in child soldier narratives speaks to the pressure of social reality on literature. Liberia and Sierra Leone in the West, Uganda and Somalia in the East, the Republic of Congo, and the Democratic Republic of the Congo are among those countries in which the use of underage combatants in armed conflicts was massive in the 199os. Hence the majority of literary works on child soldiers is produced by writers of the cited countries, many of whom live in the diaspora. ${ }^{5}$ However, the commodification of the topic as a kind of fashionable trend in African writing often addressed to a global audience outside Africa has by now also provoked severe criticism. ${ }^{6}$ During the last decade, much research has been done on the

1 Kadogo originally means "little" in Kiswahili and has become a widely used term for child soldiers in the Democratic Republic of the Congo.

2 "le roman des détritus."

3 "Ça nous touche et c' est pour ça qu' on en parle."

4 Waberi himself published the polyphonic novel Transit (2003) on the topic.

5 The exception of Nigeria whose younger generation of writers has often revisited the older Nigeria-Biafra conflict (1967-1970) during the mentioned decade after 2000 has to be mentioned here.

6 See Coundouriotis 2010; Osofisan 2019; and Raji-Oyelade 2019. 
vast corpus of child soldier narratives. With regard to African literature written in French, early masterpieces of the subgenre - such as Ahmadou Kourouma's Allahn'est pas obligé (2000) (tr. Allah Is Not Obliged, 2007) and Emmanuel Dongala's Johnny chien méchant (2002) (tr. Johnny Mad Dog, 2006) - have been studied extensively. Yet, many other writings on the topic have been neglected. In particular, the literary output of the DRC, including its diaspora authors on the topic, has been seldom studied.

Child soldiers in the DRC were prominent combatants in Désiré Kabila's Alliance des Forces Démocratiques pour la Libération du Congo (Alliance for the Democratic Forces for the Liberation of the Congo, or AFDL), which overthrew the Mobutu regime in 1997. Since then, the so-called Congo Wars (19961997; 1998-2003; 2007-2009) were followed by other "minor" armed conflicts in the Eastern parts of the country where security and peace still do not prevail today. The use of kadogos in all this warfare is a sinister reality, and Congolese authors have dealt with this reality in different ways. In this essay, I will analyse different types of texts written by and on (ex-)child soldiers, and I will show how they speak to the needs of different global and local readerships. Since the form and function of each text depends largely on its particular literary field, the sensibilities of its specific book market, and the differences between local and international publications, I will point out editorial, sociological, content, and aesthetic considerations.

Congolese literature is most often written in French and published abroad. The existence of a large intellectual diaspora outside the DRC favors literary production abroad, including publishing houses founded by Congolese in Belgium. Yet it is clear that the power of the French world republic of letters, ${ }^{7}$ centered in Paris, continues to play an important role for all Francophone literatures. ${ }^{8}$ Congolese literature in French is thus part of the broader Francophone literary field that cuts across Pierre Bourdieu's erstwhile definition of the literary field as primordially national. However, Bourdieu's seminal concept of the literary field is still useful when applied to a comparative study of plural, intersecting literary fields of postcolonial Europhone literatures. If publishing in the DRC exists according to its own rules and is embedded in its own national literary field ${ }^{9}$ (Djungu-Simba 2007), Congolese literature published there is rarely

7 See Casanova 1999, tr. 2007.

8 Two major novels on child soldiers have been published by DRC diaspora authors in "secondary" Francophone centers: Joëlle Sambi's Le Monde est gueule de chèvre (2011) in Brussels, and Blaise Ndala's Sans Capote ni kalachnikov (2017) in Montréal. I have not included these works in my analysis in this brief article.

9 See Djungu-Simba 2007. 
visible on the international scene. Nevertheless, Congolese authors based in the Congo have also written on the figure of the kadogo. In what follows, I will distinguish between testimonial narratives destinated to the global audience and narratives of reconciliation addressed to local Congolese readers. The corpus I am analyzing comprises three testimonial texts that were published in France, as well as one autobiographical narrative and one novella published in Kinshasa.

\section{Testimonial Child Soldier Narratives: A Global Genre}

After 200o, the most widely circulated works of Congolese literature have perhaps not been the innovative novels of celebrated diaspora authors such as In Koli Jean Bofane or Fiston Mwanza Mujila. Rather, in terms of its large distribution through popular outlets or via the United Nations, it is the corpus of testimonial texts written by or with ex-kadogos from the DRC that can count as "world literature" in terms of a broad reception. In this section, I will look at three texts of this kind that have been published in France: Lucien Badjoko's J'étais enfant-soldat (2005) (I Was a Child Soldier), Junior Nzita Nsuami's Si ma vie d'enfant soldat pouvait être racontée (2010) (tr. If My Life as a Child Soldier Could Be Told, 2016) and Serge Amisi's Souvenez-vous de moi, l'enfant de demain. Cahiers d'un enfant de la guerre (2011) (Remember Me, The Child of Tomorrow: The Diary of a Child Soldier). The three testimonial narratives have much in common on the content level, although they employ different aesthetics. All three narrators participated in the so-called War of Liberation in 1996-1997, in which the army of "Mzee" Laurent-Désiré Kabila overthrew the long-term regime of Mobutu Sese Seko. All three participated in the follow-up war of 1998 that opposed Kabila to his ex-allies from Rwanda and Uganda. They were trained in the same military camps and convinced to participate in an important revolutionary mission: to get rid of the dictatorship of Mobutu and the social injustice it implied. What all of the testimonies published in France by former Kadogos have moreover in common is the focus on the detailed narration of violence, of atrocities they have witnessed, experienced, or inflicted as child soldiers, and on being victims and perpetrators at the same time. This emphasis on violence has several functions. In the best of cases, it can count as an auto-therapeutic narrative that helps to cure trauma. Most certainly, it poses as a humanitarian appeal, as a wake-up call against the use of children in armed conflicts. The message "never again" is not only conveyed through an explicit paratextual framing in the case of Badjoko and Nsuami but is also even more effectively underlined through the raw rendering of detailed horrible realities. 
From a critical point of view, the function may also be to cynically serve as sensational narratives for a public that aspires to read "authentic" horror stories from Africa, especially the Congo that continues to be commonly constructed as a "heart of darkness" in Western media.

In Europe and North America, testimonial narratives on atrocities that happen elsewhere in faraway places and that simultaneously incite fear and fascination occupy an important segment of the book market. These books are made for a reader who does not necessarily want to read aesthetically refined literature, but rather one who wants to find out more about ongoing debates in relation to human rights. Africa is a prominent continent for the production of such narratives, and some of these topics include female genital mutilation, modern slavery, genocide, terrorism, and, of course, child soldiers. In Regarding the Pain of Others (2003), author Susan Sontag analyzes the particular curiosity about a faraway, atrocious "there" as mediatized trough photography and TV and observed from a secure "here." Testimonial narratives produced and marketed for a primarily Western audience can equally satisfy this curiosity. In the case of the child soldier narratives, book covers featuring young boys and girls who fiercely display or candidly embrace their Kalashnikovs serve as a visual trigger. Equally present in the press and in TV reports on African crises, these images have contributed to elevate the child soldier to an African icon in the twenty-first century. The texts under survey here confirm this iconic trend: Junior Nzita Nsuami's book cover features a photograph of the author in military clothes with his rifle; Lucien Badjoko's book cover features a young boy in civilian clothes, but with his firearm hanging from his shoulder and with a machete dangling from his waistline; and finally, Serge Amisi's book cover features a more artistic attempt, ${ }^{10}$ with the graphically abstracted photograph of the sculpture of a Kalashnikov that was made by the author.

Despite the one-sided medial construction of the African child soldier as a symbol of everything that is wrong with Africa, and despite a certain pattern of testimonial narratives tied to Western expectations, nevertheless, the testimonies of child soldiers are of course far from being irrelevant. I read them with the necessary respect, though also critically. In general, many scholars in the humanities agree that World War II ushered in an age of testimony (Wieviorka 1998). Narrative witnessing became a form of dealing with war trauma and, above all else, the industrial horror of the Holocaust. Subjectivity and individual voices were increasingly valued. Today, many scholars rightly claim

10 A multi-talented artist trained at Espace Masolo in Kinshasa, Serge Amisi was already a remarkable sculptor and a marionette puppeteer before he started writing. 
that individual testimonies are needed in order to understand collective catastrophes, whether regarding the Holocaust or, fifty years later, the Rwandan genocide, to give but two examples. However, the genre of testimony is itself a porous construction. If testimony is generally associated with life narratives built upon personal experience, the fiction on child soldiers is also often constructed around the act of witnessing (Bulte 2014). On the textual level, a clear distinction between "real" testimony and fictional testimony is not possible. This applies to all referential texts that claim to be based on life experience: the consciously or unconsciously imagined or fantasized part remains at the discretion of the author-narrator. Furthermore, in the context of testimonial child soldier narratives, one has to consider that the narrators have been traumatized by the events they witnessed. Indeed, a traumatized narrator does not necessarily control the fluid frontiers between experience and projection, or between facts and nightmares.

The Congolese kadogos who publish their narratives in the Global North inscribe themselves in a popular genre conceived for a non-African, nonCongolese audience. This type of testimonial narrative is almost always written with the help of a journalist, reader, human rights activist, or at least a translator who rearranges the text. The kind of collaboration between the two authors (or the oral narrator and the scriptwriter) is sometimes elucidated in a paratext, but more often than not, it is not satisfactorily explicated. In the case of Badjoko's narrative J'étais enfant-soldat, the book cover indicates the collaboration with French journalist Katia Clarens who has also written a short preface about the production of the text. Badjoko and Clarens met at the Bureau national de la démobilisation et de réinsertion (National Office of Demobilisation and Reinsertion) in Kinshasa in 2003, and subsequently, Badjoko told his life narrative to Clarens, who then encouraged him to write it down. Clarens comments on the process:

There were only about fifteen pages, not always comprehensible, but this was sufficient. [...] I called the publishing house. Eric Laurent, from Plon, believed in the project immediately. Thus, I returned to Kinshasa and we started to work. He was more keen about the project than I had expected. He dug, he rummaged. His head and his belly ached while he answered my questions. ${ }^{11}$

11 'Il n'y avait qu' une quinzaine de pages, pas toujours compréhensibles, mais c'était suffisant. [...] J' ai appelé les éditeurs. Eric Laurent, chez Plon, a tout de suite cru au projet. Je suis donc retourné à Kinshasa et on a commencé à travailler. Il s' est prêté au jeu au-delà 
It is important to know that in France, Plon is a publishing house that specializes in the genres of popular biography, memoir, and testimony for the general public. The result of the collaboration between the journalist Katia Clarence, the editor Eric Laurent, and the kadogo Lucien Badjoko is a testimonial book of 15 o pages, written in standard French and hence easily readable in spite of the shocking contents, a largely chronological narration with the notable exception of chapter one: by the use of an in medias res beginning, the reader is immediately projected into the horror of war, including the atrocious death of several child soldiers as observed by their comrade, the narrator Lucien. The victimization of children used in war is put at the forefront and the reader is conditioned to view the violence committed by the narrator and his comrades in light of the violence they experienced. The ending of the book is pessimistic. Speaking about the postwar period, Badjoko underlines the plight of his trauma by stating that the psychologists have failed in healing him, and he witnesses numerous other kadogos who live in the street and have remained drug addicts (156).

In 2010, Junior Nzita Nsuami published his testimonial narrative Si ma vie d'enfant soldat pouvait être racontée with Les Éditions Persée in Aix-enProvence. On its website, the publishing house describes itself as "a publisher who reveals new talents."12 This may be true, but it is also a euphemistic way to avoid speaking about the self-publishing mechanism on which this publishing house relies. In this case, we do not know how much editing of the text took place. The book's simple style shows war atrocities through the eye of an adolescent. Clearly, the author-narrator does not have a routine of writing sophisticated texts and does not pose as an accomplished writer, but as an unadorned witness. In the last chapters, Nsuami speaks about his reintegration into school and gives tribute to the humanitarians who helped him. A quadruple paratextual framing of prefaces and afterwords inserts the urgency of the text into the humanitarian discourse on children at war: the first preface is written by the director of operations of the World Bank in the DRC; the second preface is by the author himself, consisting of a passionate appeal to peace and to the intervention of humanitarian organizations against child soldiering; the first afterword is by a social scientist from the University of Liège; and the second afterword is by the representative of the Secretary General of the United Nations in the DRC. It is henceforth not surprising to learn that these institutions sponsored the publication of the book. As a matter of fact, Nsuami

de ce que j' avais espéré. Il a creusé, fouillé. Il a eu mal à la tête et au ventre en répondant à mes questions."

"L'édition révélateur de nouveaux talents." Web. June 2021. 
worked as an ambassador of goodwill with the United Nations for several years, has been active in different campaigns against child soldiering (Junior Nzita), and has founded his own NGO "Paix pour l' enfance" (Peace for Childhood) in Kinshasa. According to my own fieldwork obervations in 2016, in contrast to Badjoko's and Amisi's books, Nsuami's book was well distributed in the DRC, at least in Kinshasa, via local bookshops and the Centre Wallonie-Bruxelles.

As in the case of the beginning of Badjoko's novel, here the paratexts attracts the reader's attention to the victimization of child soldiers even before they briefly learn about the specific historical and political contexts of the war in question. The back cover of Nsuami's book displays a lengthy quote from the book which describes a scene of extreme violence that undoubtedly must have been deeply traumatizing for the witness. Capturing the mutilation of one child soldier victim, this scene has the quality of a synecdoche for the entire corpus of testimonial texts that focus on violence not only committed by but also executed on child soldiers:

As for him, when the driver started, he was still on the ground, holding the side panel of the vehicle with both hands in order to get on board. And as the vehicle was already moving, I tried to hold both his hands to pull him up to us. The rebels who could see us shot a rocket that unfortunately hit his hip and tore his body in two. On board the vehicle, I was left with the upper part of his body, the head, hands and torso ... [...] I was just thirteen; it was really a horrible experience. ${ }^{13}$

The international circulation of these testimonial texts is evident in the fact of their translations: Badjoko's J'étais enfant-soldat is available in Spanish, Catalan, and Polish, whereas Nsuami's Sima vie d'enfant soldat pouvait être racontée has been translated into German and English.

Serge Amisi's Souvenez-vous de moi, l'enfant de demain. Carnets d'un enfant de la guerre was published in 2011 by Vents d'ailleurs, a publishing house for quality literature located at the village of La Roque d'Anthéron in the South of France. The company advertises itself as offering an alternative program to established Parisian, high-brow publishing houses and as promoting Franco-

13 "Au moment où le chauffeur démarra, notre camarade était encore au sol, tenant avec ses deux mains la ridelle du véhicule pour monter. J' ai essayé de l' attraper par les deux mains pour le tirer parmi nous. Les rebelles, nous voyant, ont tiré une roquette qui le toucha au niveau de la hanche et [...] le fendit en deux. À bord du véhicule, je suis resté avec la partie supérieure de son corps, c' est-à-dire la tête, les mains et le tronc ... [...] J' avais à peine 13 ans, c'était vraiment horrible!" (2010, 35 and back cover). 
phone literatures from outside Europe. The genesis of Amisi's text is the most transparent, as it has been documented in an article by Jean-Christophe Lanquetin and Jean-Luc Raharimanana, Amisi's coauthors, in 2011. Demobilized from war in 2001, in 2004 Serge Amisi was under the tutelage of the Congolese NGO Espace Masolo ${ }^{14}$ in Kinshasa, well known for its artistic projects with street children. There he started to write his life narrative of an ex-kadogo in Lingala, using exercise books to fill up one thousand pages. Yet, the Lingala narrative was never published for three reasons: 1) There is still not a veritable book market for Lingala in the DRC, and French remains the dominant literary language. 2) The book could have put the author into political trouble. Even if there is not much explicit criticism and Kabila is lauded as a hero, some remarks on the army's plundering and raping weigh heavily. ${ }^{15} 3$ ) The form and the content do not necessarily speak to the editorial environment in Kinshasa, but rather to the global audience of the testimonial genre. Subsequently, a shortened French version was written with the help of Jean-Christophe Lanquetin, a reader for the publishing house, and the Malagasy writer Jean-Luc Raharimanana, the director of the Vent d' ailleurs book series. Lanquetin met Amisi at Espace Masolo and transcribed the author's oral translation from Lingala into French. He underlines that he consciously kept the oral and local character of Amisi's text by assuring "that the Lingala is hearable 'under' the French"16 (117). Raharimanana then received the manuscript and edited the text by transforming it into a publishable format of 254 pages.

The originality of the language that not only has the local flair of popular Congolese French but also features a highly metaphorical and fragmentary style is indeed very enriching for the text. In terms of literary aesthetics, Serge Amisi's memoir stands out as the most interesting text of the corpus. Furthermore, the narrative voice and its diction often include playful irony, a device that echoes the voice of Birahima, the protagonist of Ahmadou Kourouma's famous child soldier novel Allah n'est pas obligé. Of the three testimonials under survey, only Amisi's autobiographical narrator resembles the fictional

14 The name is a combination of French and Lingala and roughly translates to "A Place for Dialogue."

15 For instance, at some point Amisi describes plundering as a routine and compares the army of the ADLF with the army of Zaïre, quoting former president Mobutu who famously told his soldiers: "Vos armes, ce sont des pelles, et les civils, ce sont vos champs" (Amisi 241) ["Your arms are your shovels and the civilians are your fields"; my translation]. The narrator goes on to assert that as kadogos, in order to survive, they acted in the same way as Mobutu's notoriously unpaid soldiers. Therefore, a local publication of the text might have put Serge Amisi into danger.

"que le lingala s' entende «sous» le français." 
characters of Birahima and Johnny from Kourouma and Dongala's famous novels about child soldiers. Eleni Coundouriotis reads Kourouma's and Dongala's novels as "examples of radical critique of the child soldier identity as constructed by the international discourse of human rights" (195). Through the rhetoric of irony and sarcasm, Kourouma and Dongala counter the dominant discourse of testimonial narratives and certain more sentimentally inclined novels, as their novels are "cynical about humanitarianism" (194). In this respect, Serge Amisi's autobiographical narrator is closer to the fictional characters of Birahima and Johnny than to Lucien or Nzita. Amisi's editorial team confirms that "by any means, [they wanted] to avoid to produce a sensational testimonial narrative, such as they are published in Europe, which can happen very easily, given the nature of the narratives"17 (Lanquetin and Raharimanana 117; my translation). However, this ethical stance of wanting to avoid the manufacturing of a spectacle while at the same time offering an extremely violent memoir to the French audience ${ }^{18}$ remains as ambivalent a stance as the authornarrator's own positioning of his text. In contrast to Nsuami and Badjoko, who frame their narratives through a discourse not only on victimhood, but maybe more importantly on truth and authenticity, Amisi positions his narrative in an interstice between testimony and fiction, as well as between the individual and the collective. In his introduction (there are no paratexts by other people that would validate the book in the sense of an authoritative human rights discourse), Amisi declares:

This book is the narrative of my life and of that of the other children who accompanied me in these difficult moments, many of them are no longer here but their stories remain with me and I have retold them in form of fictions or as if it was my own story. ${ }^{19}$

7; my translation

Thus, Amisi creates a collective testimony of war from the point of view of the juvenile combatant who mourns his fellow fighters and who speaks for them by integrating their identities into his own literary persona. Mixing memory and

\footnotetext{
17 "[Ils voulaient] éviter à tout prix de tomber dans le témoignage spectaculaire, tels qu' on en voit publiés en Europe, ce qui est très facile vu la nature des récits."

18 The book has been scarcely, if at all, distributed in the DRC. In 2016, I couldn't find any copy in Kinshasa's bookshops or libraries. Several academic colleagues and the staff of Espace Masolo told me that, sadly, they never got hold of the book.

19 'Ce livre est le récit de ma vie et celle d' autres enfants qui m'ont accompagné dans ces moments difficiles, beaucoup ne sont plus là mais leurs histoires restent avec moi, et je les ai reprises sous forme de fictions ou comme si c'était ma propre histoire."
} 
imagination with dreams and nightmares, a hybrid form between historical testimony and a partly fictionalized trauma narrative emerges. It is a narrative of survival, in the lexicon of Valérie Dusaillant-Fernandes (107). Through the act of rewriting not only his own traumatizing memories but also those of other children, Amisi constructs himself as the kadogo witness par excellence, but without denying the role that fictionalization plays in every literary text. ${ }^{20}$

\section{3}

\section{Local Narratives of Reintegration and Reconciliation}

The rules of the literary field and book market in the DRC are completely different from the logic that prevails in France. In the DRC, the few existing publishing houses have to respond to the needs of an audience that does not buy many books, as Congolese academics, editors, and booksellers often emphasize (Mulenda; Yoka "Interview"). Furthermore, in contrast to the prestige of literature in France as a national source of pride, the Congolese state and media hardly promote literature. More often than not, literary prizes are sponsored and launched by foreign institutions such as Le Prix Zamenga of the Centre Wallonie-Bruxelles and the Prix Makomi of the Institut Français in Kinshasa, cultural institutions whose influence is mostly relevant to the small Francophone elite of the country. Nevertheless, local literary production exists, though not many authors living and publishing in the DRC have dared to write about the "Congo Wars."

In this section, I will look at two texts published in 2006 by Médiaspaul:21 Josué Mufula's testimonial text Enfant de guerre. Souvenirs d'un ex-Kadogo (War Child:Memories of an Ex-kadogo), and Lye Mudaba Yoka's youth novel La Guerre et la paix de Moni-Mambu "Kadogo" (The War and the Peace of Moni-Mambu

20 After his migration to France, where he has lived since 2008, Serge Amisi has also become an actor and a dancer in different plays such as in Djodjo Kazadi's dance performance Congo My Body (first performed in 2011), the unpublished play L'enfant de demain [Child of Tomorrow] (first performed in 2014), directed by Arnaud Chirun, which is based on Amisi's memoir, and in a French stage direction of Quebecois author Suzanne Lebeau's play Le Bruit des os qui craquent (2008) [The Sound of Cracking Bones]. All three plays focus on child soldiering in Africa. To my knowledge, Amisi has not yet had the chance to play a different role than the child soldier, although he is now in his thirties - once a kadogo, always a kadogo, it seems.

21 Médiaspaul belongs to the Catholic congregation of St. Paul. Until recently, the head of the congregation is always a missionary sent to the Congo from Italy, as is the director of the publishing house. Hence, not only a Catholic but also a European influence on the house's editorial program cannot be denied, although Congolese employees now form the majority of the active staff members. 
"Kadogo" $)^{22}$ and point out how they respond to the needs of the Congolese audience. Indeed, today, the Catholic publishing house Médiaspaul dominates the book market in the DRC. Due to its success with religious and popular literature for large audiences, it has survived for decades while other publishers have floundered. During the 197os and 198os, Médiaspaul published the best-selling novellas of Zamenga Batukezanga. The publishing house remains true to the same format: short, entertaining books with illustrations written in a simple but correct French and sold at a low price. As a former reader of the publishing house confirms (Mulenda 134), the publication politics of the company are focused on young readers. This publishing strategy implies that Médiaspaul books can potentially be used as reading material in schools, and they thus have a strong impact on the future of the Congolese society. This has proven true for both Mufula's and Yoka's books. If these texts are not part of the official school curriculum, some colleges in Kinshasa use them as reading material in their French classes, and Médiaspaul has also organized readings of the authors in schools (Mufula "La place" 143). Therefore, both books were edited several times and sold widely.

Josué Mufula's testimonial narrative is very short: it consists of forty-six pages, including five illustrations. With regard to its style of the unadorned language of a good student, Mufula's testimony resembles Nsuami's. By contrast, its near total absence of violence is striking. Here, the narrative of the 19961997 War of Liberation is extremely laconic, as it narrates the military march from Goma in the east of the vast country to Kinshasa in the west in just ten pages. The narrator speaks shortly about the hardships of military training and combat, then resumes: "That was it! It had become a mere game. And the rule became ever simpler: you have to kill if you don't want to get killed,"23 (19; my translation) but he does not go into any details about his own killings, nor does he witness torture, rape, or the loss of comrades. The story is divided into two parts of equal length: the first part speaks about the war, and the second part is dedicated to the author-narrator's desire to reconstruct his life outside the army by reintegrating back in school. ${ }^{24} \mathrm{I}$ argue that Mufula's narrative is in line with

22 Yoka, the director of Kinshasa's Institut National des Arts (National Institute of the Arts), has also published a different text on the war, Kinshasa: carnets de guerre (chroniques des années de feu et de sang) (Kinshasa: Notes from War, or A Chronicle of the Fire and Blood Years) (2005), a personal chronicle with fictional elements for an adult readership. A bilingual Lingala/French edition of the Moni-Mambu novella has been published in Dakar in 2013. Ironically, this edition is too expensive for the Congolese book market.

23 'C' était parti! C' était devenu un jeu. Et la règle devenait de plus en plus simple: il fallait tuer pour ne pas se faire tuer."

The success story that begins there is pursued in a second autobiographical volume, Je 
the Congolese public's needs. As people who have gone through war, Congolese readers tend to not want to read about atrocities as much as ask themselves how all Congolese can live together after the violence. Meanwhile, the kadogos have become young adults who often missed out on their education. Their reintegration into civil society is one of the most serious postwar challenges. Former child soldiers often count as being the "wrong" sort of people, a perspective explored in Jonathan Littell's documentary film Wrong Elements (2016) about the reintegration process of child soldiers in Uganda. In spite of their former status as heroes of the liberation (Mufula "La place" 146), the kadogos have quickly become a synonym for aggressive young men and petty criminals damaging the reconstruction of sustainable peace in a postwar society. By creating a narrative of hope, Mufula's text offers an alternative to the anguish provoked by kadogos. Therefore, Mufula does not witness violence - rather, he witnesses a productive form of resilience. His own life narrative example of a young man who overcomes the social image of the aggressive and delinquent kadogo promotes hope and reconciliation.

In his preface to Enfant de guerre, Olivier Sangi Lutondo, a Congolese poet, rightly writes: "War Child is a great victory for the demobilised, reintegrated, and above all else "re-educated" child soldiers. A flame of hope for so many others who are still part of numerous armies in Africa and elsewhere" (Mufula Enfant 3-4). Using oxymoron and hyperbole, Lutondo states that the text functions as a "violent peaceful wake-up" and even represents a "loving light for reconstructing humanity from its turmoil" (4). To put it in a less poetic nutshell, the function of this text is not the representation of a violent war experience but its appeal to peace and its proof of the possible reintegration of kadogos into civil society. God is also not absent from this narrative, which is useful not only for a Christian publishing house such as Médiaspaul but also for the average reader of the fervently Christian Congolese society. One of the text's illustrations shows the adolescent kneeling in prayer in front of a cross (40). The narrator prays and begs God to help him to persevere in his studies. Mufula's testimony carries a message of great hope by showing that it is possible to overcome the destiny of a child soldier by faith as well as by hard work. The narrator concludes the text, "Always trusting God and through hard work, I managed to overcome these hard and sad times of my youth"25 (Mufula Enfant 45; my trans-

veux devenir un homme (I Want to Become a Man) (2011) that takes the readers through Mufula's studies at the University of Lubumbashi. Mufula has been elected a member of the Congolese parliament in 2018.

25 "Confiant toujours en Dieu et entreprenant, je parvins à surmonter ces temps forts et doloureux de mon adolescence." 
lation). Different from Amisi's Souvenez-vous de moi, signs of posttraumatic stress disorder are absent from this short but luminous testimony on resilience and reintegration by Mufula.

A trinity of resilience, reinsertion, and reconciliation as introduced in Mufula's testimonial text is also the basis of Lye Mudaba Yoka's novella $\mathrm{La}$ Guerre et la paix de Moni-Mambu "Kadogo" (The War and the Peace of MoniMambu "Child Soldier"). Moni-Mambu is a character type stemming from oral tradition whose adventures are well known on both sides of the Congo River. The Kikongo-Lingala name means "the one who has seen everything" (Yoka La Guerre 3). The role of a witness is thus implied in the name. Yoka reincarnates the oral tradition's Moni-Mambu as a different kind of adventurer of modern times, a kadogo who witnesses the war and its aftermath. In contrast to its Tolstoian title, which suggests a double narrative on war and peace, the novel speaks little about the war itself as the narrative takes place in postwar DRC. Just as in Mufula's narrative, the depiction of violence is avoided. For Yoka, the absence of violence was a conscious choice against what he calls "the over-mediatization of violence" 26 ("On ne guérit" 172). Therefore, by means of a succinct flashback, the omniscient narrator resumes Moni-Mambu's war experience in two pages and, by using metaphor and simile, offers a figurative summary in just one sentence: "Then, for the child soldier it was like a film passing in quick sequence, like a succession of nightmares, hell ..." ${ }^{27}$ (Yoka $\mathrm{La}$ Guerre 5; my translation).

The text centers on the return of the young man from Kinshasa to his village in the Eastern Congo where he was first recruited. On his long route across the gigantic territory of the DRC, Moni-Mambu encounters several adventures that help him understand the history of his country and his own role in it. But his trip home is also a path of reflection, regret, and penitence. The latter are necessary to allow for a convincing narrative of reconciliation and reinsertion. The desire for peace has to pass through a process of growing consciousness about guilt, sincere regret, and the will to redress one's wrongs. ${ }^{28}$ Moni-Mambu meets a Belgian missionary who rejects him because of his participation in the war and preaches morality. His path crosses with a dedicated "Mobutiste,"

\footnotetext{
26 "la sur-médiatisation de la violence."

27 "Puis, pour l' enfant-soldat, ce fut un film en séquences précipitées, comme une succession de cauchemars, l'enfer ..."

28 This line of thought is well inscribed into the chapter titles of the novella: the word 'peace' features in six of the ten headings. By contrast, the negatively connotated words 'criminal', 'merciless' and 'thief' used in three headings recall Moni-Mambu's infamous past. Finally, he will literally need to 'vomit his remorse' (title of chapter $\mathrm{x}$ : "Vomir les remords") in order to achieve penitence (chapter XI: "Pénitence").
} 
who reproaches the stupidity of the kadogo's revolution. Now, after the war, as a politically conscious young man, the protagonist refuses to surrender to guilt in the name of these two moralizing ideologies. Though by then he sincerely regrets his evil deeds during the war, it is not in the name of either the Catholic/colonial civilizing mission or of the former deeply corrupt system of a failing state that Moni-Mambu can accept to be judged.

Rather, it is the reunion with Nyota, a girl he had raped during the war, which will be the key to the boy's penitence and redemption. He finds the victim of his own violence who still suffers from post-rape trauma and is living in a psychatric ward. After his sincere regret, the young woman grants him remission and Moni-Mambu's reconciliation with Nyota culminates in their marriage. At first glance, this love story seems so incredible that it weakens the plot considerably. It is questionable if the young Congolese readership can accept to be convinced by such a fairy-tale turnaround in the story. However, on a different level, it is here that the figurative quality of the novel achieves its peak. Pierre Halen proposes an allegorical reading of the plot: "This happy ending should in reality not be read as the ending of a doubtful melodrama, but as an allegory: Nyota means 'star' and refers to the Congolese nation since the end of the 19th century"29 (103; my translation). The symbol of the star that had vanished from the flag when the country was renamed Zairre in 1971, is notably the central element of today's D RC's flag. ${ }^{30}$ In spite of her profound trauma, which symbolizes the wounds of the nation, allegorical character Nyota owns the power of resilience and of forgiveness that will allow her to build the future through the iconoclast union with her rapist. In a lyrical passage of the novel, Nyota identifies explicitly with the territory of Congo (Yoka La Guerre 116). This figuration of a country or even of the African continent through the allegory of a woman is nothing new in African literature since the times of Négritude, and Yoka's allegorical use of gender is reminiscent of Léopold Sédar Senghor's famous poems "Femme noire" and "Congo." However, in light of the referential link that exists between the testimonial narratives of Congolese kadogos and Yoka's fiction, the novel's plot has the quality of a poetic testimony on the urgency of reconciliation for DRC's youth. Nyota's, read as the nation's, strong will to forgive and to move on allows for the kadogo's reintegration into society - as a son and as a

29 "ce happy end est en réalité moins à lire comme la fin d'un douteux mélodrame que comme une allégorie: Nyota veut dire «étoil», et renvoie depuis la fin du XIX siècle à la nation congolaise."

30 Curiously, a colonial symbol that had been used for the Congo since Léopold the II, notorious Congo Free State has thus been recycled by the new regime of the DRC to mark its distance from the Mobutu era. 
husband - and hence fosters the reconstruction of the nation. Furthermore, as Halen writes, the novella "does not merely preach reconstruction: it constructs the memory that is necessary for it by using the form of a narrative exploration of the territory and also of history"31 (103; my translation).

\section{$4 \quad$ Conclusion}

My analysis has identified how child soldier narratives are framed differently and how diverse editorial and narrative strategies target global and local readerships. The literary manufacturing and marketing of testimonial child soldier narratives in France relies heavily on the iconic function of the child soldier as a perpetrator-victim in medial and human rights discourses. By contrast, the Congolese audience seeks hope and reconciliation in a postwar society whose children have been misused. Therefore, narratives on the power of resilience and the reintegration of kadogos prevail in the DRC. While the redemption and reconstruction of the individual and the nation are brought forward in Josué Mufula's autobiographical testimony, as well as in Lye Mudaba Yoka's allegorical fiction, the urgency of witnessing defines the corpus as a whole. Strikingly, the child soldier as a witness narrates and/or acts differently according to the context of the editorial framing and target audience. Lucien Badjoko and Junior Nzita Nsuami employ the depiction of graphic violence as a means to shock and/or impact international audiences, whereas the DRC-based authors avoid showing violence so as not to re-traumatize a war-torn Congolese public. In its first draft not destinated to a European audience, Serge Amisi's text has the quality of a trauma narrative in which fugitive memories of collective violence are reworked through a laconic, though rhetorically powerful language by the use of French with Lingala shining through it. Souvenez-vous de moi, l'enfant de demain might be a text that appeals to both local and global audiences, but alas, not many Congolese readers based in their home country have had the chance to read it yet.

31 "ne se contente pas de prêcher la reconstruction: il construit la mémoire nécessaire à celleci, sous la forme d'une exploration narrative du territoire mais aussi de l'Histoire." 


\section{Works Cited}

Amisi, Serge. Souvenez-vous de moi, l'enfant de demain. Carnets d'un enfant de la guerre. La Roque d'Anthéron: Vents d' ailleurs, 2011.

Badjoko, Lucien, and Katia Clarens. J'étais enfant-soldat. Paris: Plon, 2003.

Bulte, Marie. "L' enfant-soldat: la puissance d'un témoin." Voix plurielles 11:2 (2014), 8291.

Casanova, Pascale. La République mondiale des lettres. Paris: Editions du Seuil, 1999.

Casanova, Pascale. The World Republic of Letters. Cambridge: Harvard UP, 2007.

Coundouriotis, Eleni. "The Child Soldier Novel and the Problem of Arrested Historization." Journal of Human Rights 9 (2010), 191-206.

Djungu-Simba, Charles K. Les Ecrivains du Congo-Zaïre. Approches d'un champ littéraire africain. Metz: Université Paul Verlaine, 2007.

Dongala, Emmanuel. Johnny, chien méchant. Paris: Le Serpent à Plumes, 2002.

Dongala, Emmanuel. Johnny Mad Dog. Trans. Maria Louise Ascher. New York: Picador, 2006.

Dusaillant-Fernandes, Valérie. "Le récit de survivance de Serge Amisi: modalités d' adaptation textuelle et stratégies d' ajustement." Dialogues francophones 21 (2015), 107-20.

Gehrmann, Susanne. "The Child Soldier's Soliloquy: Voices of a New Archetype in African Writing." Études littéraires africaines 32 (2011), 31-43.

Halen, Pierre. "L' enfant-soldat vu par la fiction africaine: à propos de La Guerre et la paix de Moni-Mambu par André Lye Yoka." Études littéraires africaines 32 (2011), 91104.

Junior Nzita Nsuami: A Former Child Soldier Rebuilds His Life. Web. 29 May 2013. https://childrenandarmedconflict.un.org/2013/o5/junior-nzita-former-child -soldier/. June 2021.

Kourouma, Ahmadou. Allah n'est pas obligé. Paris: Seuil, 2000.

Kourouma, Ahmadou. Allah Is Not Obliged. Trans. Frank Wynne. New York: Anchor, 2007 .

Lanquetin, Jean-Christophe, and Jean-Luc Raharimanana. "Biographie du livre: dialogue sur la genèse." Études littéraires africaines 32 (2011), 116-25.

Lebeau, Suzanne. Le Bruit des os qui craquent. Montréal: Leméac, 2009.

Littell, Jonathan. Wrong Elements. Documentary. Belgium/France/Germany, 2h 3om, 2016.

Mufula, Josué Jive. Enfant de guerre. Souvenirs d'un ex-Kadogo. Kinshasa: Médiaspaul, 2006.

Mufula, Josué Jive Ushindi. Je veux devenir un homme. Kinshasa: Médiaspaul, 2011.

Mufula, Josué. “La place de l' enfant n' est pas dans l'armée." In The Ubiquitous Figure of the Child Soldier: Interviews with African Writers, Academics and Cultural Activists 
followed by a Comprehensive Bibliography. Eds. Susanne Gehrmann and Charlott Schönwetter. Trier: wVT, 2019, 139-51.

Mujila, Fiston Mwanza. Tram 83. Trans. Roland Glasser. London: Jacaranda, 2015.

Mulenda, Antoine. "La réintégration dans la société est toujours très difficile et cela est plus vrai qu'un roman." In The Ubiquitous Figure of the Child Soldier: Interviews with African Writers, Academics and Cultural Activists followed by a Comprehensive Bibliography. Eds. Susanne Gehrmann and Charlott Schönwetter. Trier: wVT, 2019, 131-38.

Ndala, Blaise. Sans Capote ni kalachnikov. Montréal: Mémoire d' encrier, 2017.

Nganang, Patrice. Manifeste d'une nouvelle littérature africaine. Pour une écriture préemptive. Paris: Homnisphères, 2007.

Nsuami, Junior Nzita. Si ma vie d'enfant soldat pouvait être racontée. Aix-en-Provence: Persée, 2010.

Nsuami, Junior Nzita. If My Life of a Child Soldier Could Be Told. Trans. Béatrice Bolz. Ottawa: Perseus; Bern: THAC, 2016.

Osofisan, Femi. "Once it becomes an item of commerce, I lose interest." In The Ubiquitous Figure of the Child Soldier: Interviews with African Writers, Academics and Cultural Activists followed by a Comprehensive Bibliography. Eds. Susanne Gehrmann and Charlott Schönwetter. Trier: wVT, 2019, 85-90.

Raji-Oyelade, Aderemi. "There is a very thin line between fiction and reality." In The Ubiquitous Figure of the Child Soldier:Interviews with African Writers, Academics and Cultural Activists followed by a Comprehensive Bibliography. Eds. Susanne Gehrmann and Charlott Schönwetter. Trier: WVT, 2019, 99-104.

Sambi, Joëlle. Le Monde est gueule de chèvre. Brussels: Biliki, 2007.

Sontag, Susan. Regarding the Pain of Others. New York: Farrar, Straus and Giroux, 2003.

Waberi, Abdourahman A. Transit. Paris: Gallimard, 2003.

Waberi, Abdourahman A. "Ça nous touche et c' est pour ça qu'on en parle." In The Ubiquitous Figure of the Child Soldier: Interviews with African Writers, Academics and Cultural Activists followed by a Comprehensive Bibliography. Eds. Susanne Gehrmann and Charlott Schönwetter. Trier: WVT, 2019, 44-59.

Wieviorka, Annette. L'ère du témoin. Paris: Plon, 1998.

Yoka, Lye Mudaba. Kinshasa: Carnets de guerre (chroniques des années defeu et de sang). Kinshasa: Editions universitaires africaines, 2005.

Yoka, Lye Mudaba. La Guerre et la paix de Moni-Mambu “Kadogo." Kinshasa: Médiaspaul, 2006.

Yoka, Lye Mudaba. La Guerre et la paix de Moni-Mambu "Kadogo"/Bitumba mpe kimiaya Moni-Mambu «Kadogo». Trans. René Hardy Mone Mabonga and Célestin Ndondo Aley Yinda Bow. Dakar: Abis éditions, 2013.

Yoka, Lye Mudaba. "On ne guérit pas d'une cicatrice; elle laisse des traces, c'est un 
tatouage qui nous reste au cœur." In The Ubiquitous Figure of the Child Soldier:Interviews with African Writers, Academics and Cultural Activists followed by a Comprehensive Bibliography, Eds. Susanne Gehrmann and Charlott Schönwetter. Trier: WVT, 2019, 166-77. 